\title{
Correction to: Modeling the acute effects of exercise on glucose dynamics in healthy nondiabetic subjects
}

\author{
Spencer Frank ${ }^{1,2}$ (D) $\cdot$ Abdulrahman Jbaily $^{1,2} \cdot$ Ling Hinshaw $^{3} \cdot$ Rita Basu $^{4} \cdot$ Ananda Basu $^{4} \cdot$ \\ Andrew J. Szeri ${ }^{1,5}$
}

Published online: 1 June 2021

(C) Springer Science+Business Media, LLC, part of Springer Nature 2021

\section{Correction to: \\ Journal of Pharmacokinetics \\ and Pharmacodynamics (2021) 48:225-239 \\ https://doi.org/10.1007/s10928-020-09726-9}

The original version of this article contained a typo in table 1. In table 1, the units in three parameters read as $\mathrm{mL} /$ $\mathrm{kg}$, instead they should read $\mathrm{dL} / \mathrm{kg}$. The units were reported correctly elsewhere in the manuscript and the results are not affected by the typo. Please find below the corrected Table 1:

The original article can be found online at https:// doi.org/10.1007/s10928-020-09726-9.

Spencer Frank

spencerfrank@berkeley.edu

1 Department of Mechanical Engineering at the University of California Berkeley, Berkeley, USA

2 Present Address: Dexcom in San Diego, San Diego, CA, USA

3 Division of Endocrinology at Mayo Clinic, Rochester, USA

4 Present Address: Division of Endocrinology at the University of Virginia School of Medicine, Charlottesville, USA

5 Present Address: Department of Mechanical Engineering at the University of British Columbia, Vancouver, USA 
Table 1 Parameters used in glucose dynamics model for healthy nondiabetic subjects

\begin{tabular}{|c|c|c|c|c|}
\hline Parameter & Description & Unit & Value & Source \\
\hline $\mathrm{r}_{\text {brain }}^{G}$ & Metabolic clearance rate of glucose in the brain & $\mathrm{mg} / \mathrm{min}$ & 71 & [32, p. 219] \\
\hline $\mathrm{r}_{\text {heart }}^{G}$ & Metabolic clearance rate of glucose in the heart & $\mathrm{mg} / \mathrm{min}$ & 3.7 & [32, p. 219] \\
\hline $\mathrm{r}_{\text {kidney }}^{G}$ & Metabolic clearance rate of glucose in the kidneys & $\mathrm{mg} / \mathrm{min}$ & 3.7 & {$[32$, p. 219] } \\
\hline $\mathrm{r}_{\text {gut }}^{G}$ & Metabolic clearance rate of glucose in the gut & $\mathrm{mg} / \mathrm{min}$ & $16.6^{\mathrm{b}}$ & [32, p. 219] \\
\hline $\mathrm{r}_{\text {peri }}^{G}$ & Basal metabolic clearance rate of glucose in the peripheral tissue & $\mathrm{mg} / \mathrm{min}$ & 45.2 & {$[32$, p. 219] } \\
\hline $\mathrm{r}_{l i v}^{G}$ & Basal metabolic clearance rate of glucose in the liver & $\mathrm{mg} / \mathrm{min}$ & $14.8^{\mathrm{b}}$ & [32, p. 219] \\
\hline $\mathrm{r}_{S M_{\text {ins }}}^{G}$ & Insulin sensitivity of glucose clearance in skeletal muscle & $\mathrm{mg} / \mathrm{min}$ per $\mu \mathrm{U} / \mathrm{mL}$ & 5 & [34] \\
\hline $\mathrm{r}_{S M_{e x r}}^{G}$ & Exercise sensitivity of glucose clearance in skeletal muscle & $\mathrm{mg} / \mathrm{min}$ per $E$ & 860 & {$[2,16,17,35,36]^{\mathrm{c}}$} \\
\hline$V_{C S_{N}}^{G}$ & Normalized volume of distribution of glucose in circulatory system & $\mathrm{dL} / \mathrm{kg}^{\mathrm{a}}$ & 0.7 & [7] \\
\hline$V_{S M_{N}}^{G}$ & Normalized volume of distribution of glucose in skeletal muscle & $\mathrm{dL} / \mathrm{kg}^{\mathrm{a}}$ & 0.96 & {$[7]$} \\
\hline$V_{S M_{N}}^{\text {tiss }}$ & Normalized volume of tissue in skeletal muscle & $\mathrm{mL} / \mathrm{kg}^{\mathrm{a}}$ & 540 & {$[41]$} \\
\hline$\tau_{l i v}$ & Time lag of insulin action of liver glucose uptake & $\min$ & 25 & [7] \\
\hline$Q_{d_{\text {rest }}}$ & Tissue perfusion rate in skeletal muscle tissue at rest & $\mathrm{mL}_{b} / \mathrm{mL}_{\text {tiss }} / \mathrm{min}$ & 0.038 & [41] \\
\hline$P S_{d_{r e s t}}^{G}$ & Capillary permeability surface area to glucose during rest & $\mathrm{mL}_{b} / \mathrm{mL}_{\text {tiss }} / \mathrm{min}$ & 0.01 & [38-40] \\
\hline$R_{d}$ & Capillary recruitment factor in delivering (SM) tissue & 1 & 1.46 & {$[19,56,57]^{\mathrm{c}}$} \\
\hline$\gamma$ & Capillary recruitment saturation rate & 1 & 10 & {$[19,56,57]^{\mathrm{c}}$} \\
\hline$\lambda_{d}$ & Sensitivity of tissue perfusion rate to exercise & $\mathrm{mL}_{b} / \mathrm{mL}_{\text {tiss }} / \mathrm{min}$ per $E$ & 1.1 & {$[37]$} \\
\hline$\tau_{E G P}$ & Time lag of exercise action on endogenous glucose production & $\min$ & 20 & {$[16,17]^{\mathrm{c}}$} \\
\hline$\eta$ & Maximum exercise action on endogenous glucose production & 1 & 4 & {$[16,17]^{\mathrm{c}}$} \\
\hline$V_{S M_{N}}^{I}$ & Normalized volume of distribution of insulin in skeletal muscle & $\mathrm{dL} / \mathrm{kg}^{\mathrm{a}}$ & 1.2 & {$[7,42]$} \\
\hline $\mathrm{r}_{S M_{N}}^{I}$ & Normalized metabolic clearance rate of insulin in skeletal muscle & $1 / \min$ & 0.02 & {$[58-60]^{\mathrm{c}}$} \\
\hline$P S_{d_{r e s t}}^{I}$ & Capillary permeability surface area to insulin during rest & $\mathrm{mL}_{b} / \mathrm{mL}_{\text {tiss }} / \mathrm{min}$ & 0.005 & {$[39,40]$} \\
\hline$h$ & Hematocrit percentage in blood & 1 & 0.4 & {$[43]$} \\
\hline
\end{tabular}

${ }^{a}$ Multiplied by body weight (BW) prior to being used in model. See demographics for BW

${ }^{\mathrm{b}}$ Adjusted to ensure that total liver uptake is approx $50 \%$ of ingested glucose [33, 46]

${ }^{c}$ Parameter is derived from data taken from specified sources

Publisher's Note Springer Nature remains neutral with regard to jurisdictional claims in published maps and institutional affiliations. 